\title{
Changing housing policy in Vietnam: Emerging inequalities in a residential area of Hanoi
}

\author{
Katherine V. Gough ${ }^{\mathrm{a}, *}$, Hoai Anh Tran ${ }^{\mathrm{b}}$ \\ a Department of Geography and Geology, University of Copenhagen, Oestervoldgade 10, 1350 Copenhagen K, Denmark \\ ${ }^{\mathrm{b}}$ School of Global Studies, University of Gothenburg, Sweden
}

\section{A R T I C L E I N F O}

\section{Article history:}

Received 16 September 2008

Received in revised form 10 March 2009

Accepted 15 March 2009

Available online 24 April 2009

\section{Keywords:}

Housing

Housing policy

Inequalities

Urban

Hanoi

Vietnam

\begin{abstract}
A B S T R A C T
This paper discusses the housing situation of urban dwellers in Hanoi in the transition period from state housing provision to privatisation and market-driven housing. Based on field studies in a residential area of Hanoi with Soviet-style apartment blocks, the paper shows how new housing policies are contributing to strengthening inequality as 'winners' and 'losers' emerge. The entrepreneurial, the better off, and those of higher social status have encountered greater opportunities to improve their economy and housing situation. The less well-off residents, who typically have a lower social status, are losing out under the new housing policy. Unable to rely on state provision of housing, and at times denied the possibility of buying their apartments, they face an uncertain future as plans to upgrade the areas may well force them out. The youth are increasingly facing differentiated opportunities mainly dependent on the extent of parental financial support. Youth from better off households have access to housing purchased for them by their parents whereas youth from poorer families have to settle for long-term living in overcrowded parental homes. The paper shows how despite moving towards a more market-oriented economy, the new housing system is still built on old ideologies and supports the old hierarchy. Inequality is not just emerging between different housing areas but also within them.
\end{abstract}

() 2009 Elsevier Ltd. All rights reserved.

\section{Introduction}

Hanoi has undergone a dramatic physical and social transformation since the introduction in 1986 of economic renovation policies called Doi Moi (Leaf, 1999). The reforms aimed to create a hybrid third way, an economy in-between a command-based system and capitalism, where resource allocation is determined by a mix of market mechanisms and state control (Smith and Scarpapi, 2000). Programmes of gradual economic reform have been introduced and the country has opened up to international capital resulting in Vietnam's growth averaging about 9\% annually for most of the 1990s. Doi Moi, however, has not only affected the economy but has also resulted in changes being made to the urban planning process (Surborg, 2006). It is the impact of some of the changes in urban planning in Hanoi that is the focus of this paper.

Throughout Vietnam's history, successive regimes have 'imposed different buildings, public spaces and monuments upon the landscape' (Thomas, 2002, p. 1613). Before colonialism by European powers, the Vietnamese and Chinese built pagodas and temples. The French colonial period saw wide streets and Frenchstyle buildings. This was followed by the Soviet-inspired period

\footnotetext{
* Corresponding author. Tel.: +45 35322569; fax: +45 35322501.

E-mail addresses: kg@geo.ku.dk (K.V. Gough), hoai.tran@globalstudies.gu.se (H.A. Tran).
}

with its functional apartment blocks linked to places of employment. More recently, high-rise apartment blocks and multi-storey town houses are being built, some as gated communities. Smith and Scarpaci (2000, p. 754) have argued that one of the most prominent features of the current situation is the way in which 'housing is beginning to reflect the emerging income and class differentials'. Large houses constructed in a Vietnamese-French Gothic style dominate the top end of the housing market whereas dilapidated socialist blocks are at the lower end. By exploring the housing opportunities of households living in a low-income residential area of Hanoi, this paper shows how inequality does not just exist between different housing types but is emerging within them.

The paper focuses on the housing situation of households living in Soviet-style housing blocks in the transition period from state housing provision to privatisation and market-driven housing. Drawing on the experiences of a range of households it is shown how the changes to housing policy have resulted in there being both 'winners' and 'losers'. The paper starts by providing an overview of the changing nature of housing policy in Hanoi. The collection of the data and the characteristics of the neighbourhood of Quynh Mai are then presented. The analysis of the empirical data is divided into three sections. First, the impact of the new economy on housing opportunities is discussed. Second, the focus turns to the way in which the new housing policy continues to support people who were favoured by the old system. Third, the unequal 
opportunities presented by the new housing market, especially for young people, are analysed. The resourcefulness of the residents, who find many creative solutions to deal with overcrowding and lack of private space via subdivision, multiple uses of space, as well as finding various ways to extend their home is highlighted. The overriding theme, however, is the way in which the changing housing policy has brought about unequal opportunities for residents.

\section{Changing housing policy in Hanoi}

Prior to Doi Moi, broadly speaking there were three main types of accommodation in Hanoi. The 'tube houses' of the Ancient Quarter, which have a narrow frontage and are very deep; the large villas of the French Quarter, which had been subdivided and reallocated to multiple families; and state housing, mainly apartment blocks from the socialist period with collective kitchens and communal toilets (Smith and Scarpaci, 2000) (see Fig. 1). The latter housing type was built during the 1960s-1980s, when a top-down planning process following the Soviet model was implemented in Vietnam. The state (and its institutions) held a monopoly of city planning as well as housing design and production. Uniform residential areas were constructed with the intention of providing families with the same living space and living conditions levelling out social differences in the process in line with socialist ideology (Trinh and Parenteau, 1992; Waibel, 2004). The state found it difficult to meet the demand for housing from its own civil services hence apartments were allocated to state employees according to their rank and number of years of employment and only about one third were in fact accommodated (Drakakis-Smith and Dixon, 1997). The rents were nominal and maintenance was almost nonexistent. As Smith and Scarpaci (2000) have claimed, 'On the eve of doi moi, housing conditions in Hanoi were both insufficient and poor' (Smith and Scarpaci, 2000, p. 753). On average there were only $4 \mathrm{~m}^{2}$ per capita with 40,000 households having less than $2 \mathrm{~m}^{2}$ per capita.

Since the introduction of Doi Moi in 1986, the government has introduced a range of policies to encourage individuals, organisations and companies to engage in housing production. This has resulted in a boom in housing construction in Hanoi. The old tube houses of the Ancient Quarter are rapidly being replaced by multi-story houses and hotels. The French Colonial Quarter has become an incipient Central Business District favoured by foreign and domestic investors and embassies. In order to make way for the businesses and diplomats, the former residents of the villas, often multiple families, were displaced (Logan, 2000). Whilst some of the French colonial houses have been preserved, a considerable number have been demolished and replaced by highrise office blocks (Waibel, 2004). New housing areas are also emerging where initially much of the construction was carried out by individuals who built private houses of 2-5 storeys. Between 1985 and 1997, about 70\% of new accommodation was constructed using financial capital from household and private sources (Phe, 2002; Quang and Kammeier, 2002). In order to further boost housing development, the government introduced a series of directives to encourage large-scale housing investment by major developers, such as exemption of land premium and tax breaks. This resulted in the construction of large-scale highrise housing areas in the late 1990s and especially since the turn of the century. Between 1998 and 2005, more than 4 million $\mathrm{m}^{2}$ of housing was constructed in Hanoi of which $60 \%$ was built by private companies (JICA and People's Committee of Hanoi, 2007). Average living areas have also increased; in 1954 average living areas were $6 \mathrm{~m}^{2}$ which had fallen to $4 \mathrm{~m}^{2}$ by 1993 (Drakakis-Smith and Dixon, 1997) but by 1999 had increased to $10.5 \mathrm{~m}^{2}$ (JICA and Hanoi People's Committee, 2007).
Housing demand has increased rapidly since transition resulting in the possibility of making large economic gains through the private housing market as housing and land prices in central-city locations have skyrocketed (Kim, 2007; Yeung, 2007). Real estate prices are reported to have risen by an unprecedented $500 \%$ in central Hanoi between 1990-1993 (Drakakis-Smith and Dixon, 1997). By 2006, the price of new apartments in Hanoi reached US $\$ 100,000-200,000,10-20$ times the annual income of an average worker (Tran and Yip, 2008). Parallel to supporting housing production by the private sector, the government launched a programme to privatise the existing state-owned housing stock. The sale of state-owned housing was declared a means to reduce state involvement in housing and involve people in the management of the existing housing stock. By 2006, 12 years after the launch of privatisation, $68 \%$ of state-owned housing in Hanoi had been privatised (ThanhNienOnline 19/11/2007) including many, but not all, of the Soviet-style apartment blocks where current tenants have been given the chance to buy their apartments. Some owners have subsequently sold their newly acquired apartments. Housing transactions also occur between tenants via the sale of 'use-rights', an illegal but tolerated practice which started before privatization but has increased multi-fold since. A private rental housing market has emerged where owners rent out their apartments and tenants sublet their 'use-right' (Tran and Dalholm, 2005).

While the shift to a market-driven planning system has contributed to an increase in housing construction and more living space in Hanoi, access to housing and opportunities for individuals to improve their housing situation are distributed unevenly between different social groups. The newly produced houses and apartments available in the private market mainly cater for higher income groups. The new housing policies have paid little attention to middle and low-income groups although there has been a degree of social ambition to take care of the housing needs of some socially disadvantaged groups. A few state projects have resulted in a limited number of apartments being built for the very poor who qualify for social welfare, and some households deemed to be in extreme hardship have received housing upgrading assistance. In order to build up an affordable housing stock, the local authorities in Hanoi have introduced several policy measures to acquire newly produced dwellings from private developers (in exchange for a reduction in land premiums) which are then sold at cost price to state employees who are in need of housing. However, due to poor administration and corruption, these seldom reach the target groups (Tran and Yip, 2008). In an effort to address the issue of housing affordability, the 2006 Housing Law emphasised the need to develop 'social housing'. However, social housing is not aimed at socially vulnerable groups but is specifically targeted at 'state employees, officials, government staffs, military officers, professionals in the defence forces' and 'workers working in the economic zones, industrial areas, production areas, high tech areas' (Article 53, 2006 Housing Law). Thus the new housing policy in transitional Vietnam, while focusing on commercial housing for the better off, also continues to support the previously privileged group of civil servants, especially senior ones, and excludes others in need such as low paid workers in the private sector, people who engage in small family businesses, those who do not have regular work, and the unemployed. This has contributed to enhancing inequality between social groups and strengthening the existing social hierarchy (Tran and Dalholm, 2005).

\section{Setting the scene: Quynh Mai and methodology}

In the Soviet era, residential areas were planned according to Soviet principles. Four or five storey walk up apartment blocks were built in close proximity to shops, schools and recreation 


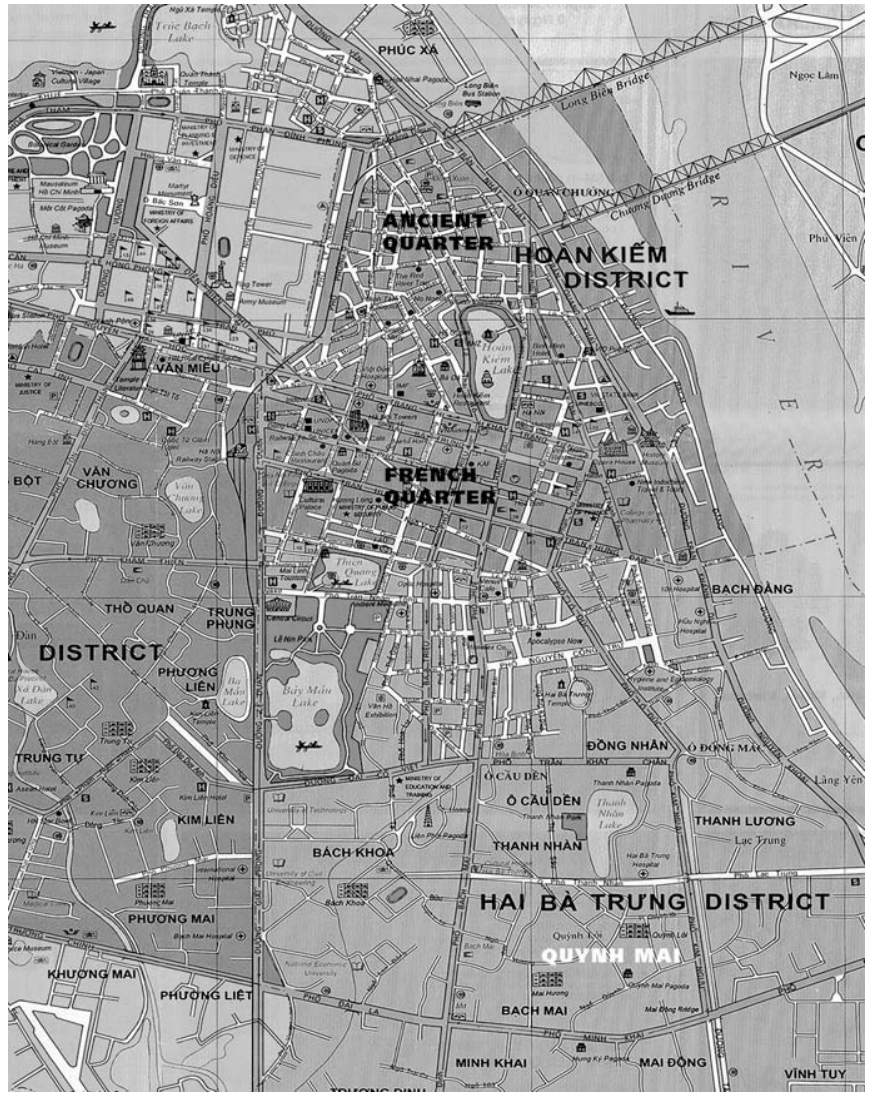

Fig. 1. Map of Hanoi showing location of Quynh Mai.

areas. The residential areas were based on a population formula of 7000-15,000 people living in an area of 15-25 hectares (Quang and Kammeier, 2002; Tran et al., 2005). Hanoi has 24 such residential areas, where a total of 450 blocks provide a living area of one million $\mathrm{m}^{2}$ for a population of approximately 140,000 . Many of these housing blocks are currently in a dilapidated state and face serious maintenance problems and overcrowding (van Horen, 2005; Tran and Dalholm, 2005).

Quynh Mai, one such area located to the south of Hanoi's city centre (see Fig. 1), consists of 17 parallel apartment blocks covering an area of 8 hectares, built during the 1960s and 1970s (see Fig. 2). In the older blocks, each floor consists of 8-10 apartments of $18 \mathrm{~m}^{2}$ sharing a common kitchen and toilet. In the later blocks, the apartments are larger (24-28 $\left.\mathrm{m}^{2}\right)$ and consist of two rooms, a kitchenette and toilet. Many of the blocks in Quynh Mai belonged to a state-owned textile factory called the 8th of March Factory and were used to house their workers. Consequently, approximately two-thirds of households worked at the factory and one-third were civil servants (Luan, 2000). With the implementation of privatisation, the blocks became the responsibility of the municipal housing authority. The sale of apartments was implemented in 1999 but stopped after one year because the blocks were considered to be of too poor quality and in need of being demolished and rebuilt. This resulted in not all residents who wanted to purchase their apartments being able to become owners. Consequently, there is mixed ownership in the blocks with $45 \%$ being owners (Yip and Tran, 2008). Plans exist to redevelop Quynh Mai; the blocks are to be demolished and high-rise apartments built in their place. The redevelopment is to be done by private developers or public developers on market terms. The plan is that the current owners will be relocated in the same area but as the apartments will be larger, the residents will have to pay more. Once apartments have been allocated to the current residents, the company can sell the rest of the apartments on the market. Quynh Mai, however, with its relatively poor population, is not considered very attractive by developers and the plans are at a standstill.

This paper builds upon data collected in two separate studies conducted in Quynh Mai. In both cases Quynh Mai was selected as being representative of a relatively run-down residential area of lower social status. One study aimed to investigate the residents' housing situation following privatisation. ${ }^{1}$ The paper builds upon in-depth interviews from this study held with 20 households in Quynh Mai. The interviews focused on the residents' views of their current housing situation, being an owner or tenant, the privatization process, the meaning of ownership, and their housing plans and wishes. The interviews were semi-structured; a list of pre-drafted questions was used as a checklist, but the interviewees were given the space to tell their stories in their own way. The interviews took from one to two hours and were taped. Drawings of the layouts were made and the furnishings and use of space was noted. In the second study, the focus was on youth and the home. Young people were asked about their living conditions, their daily lives, the meaning of home, and their hopes and plans for establishing their own home. This paper builds upon 25 in-depth interviews held with young people which were taped and later transcribed. A range of youth were selected for the interviews, varying by age (14-27), level of schooling, occupation, household composition and marital status. The interviews took place in the young people's homes where sketches of the apartment layouts were drawn and parents were asked supplementary details about their housing histories. ${ }^{2}$ Within both studies a range of interviews were conducted with relevant officials from ministerial down to ward level. By combining the two data sets we not only strengthen the empirical material upon which the paper is based but have also benefited from discussions which have arisen from the findings of the two studies. Our aim here is not to present statistical evidence but through analysing a number of cases draw out the range of complex and interwoven housing strategies exploring who are the 'winners' and 'losers' in the new housing market.

\section{New economy: creating differing housing opportunities}

Thomas (2002, p. 1613) has argued that 'Urban space in Vietnam has been transformed not so much by architectural reconfigurations but by the use of available space brought about by economic transformations'. Doi Moi reforms have changed the previous lifetime employment security of many Vietnamese with major retrenchments taking place in the state sector. One result of the switch to a market economy has been increased opportunities for new income-generating activities as the private sector has been legalised (Turner and Nguyen, 2005). The new market economy is providing some people with the chance of obtaining new types of jobs with better incomes, in particular, people who work in business such as for foreign investors or joint-venture companies. As Luan and Vinh (2001, p. 21) have claimed, the market economy 'has now become ubiquitous: its presence can be felt in every household and everybody's life is now affected by it'. This applies not only to employment opportunities but also to consumption patterns. A highly diverse street-trading culture, which was restricted during the communist collectivization era, is booming characterized by people gathering together at noodle soup shops, in parks, and around pavement sellers (Thomas, 2002). Some of the new commercial activities occupy public spaces and the pavements are lined with small businesses. Residents also extend their

\footnotetext{
${ }^{1}$ It formed part of a larger study conducted in six different housing areas of Hanoi (see Tran and Dalholm, 2005).

${ }^{2}$ For more details of the methodology and the larger project of which this study forms a part, see Hansen et al. (2008).
} 


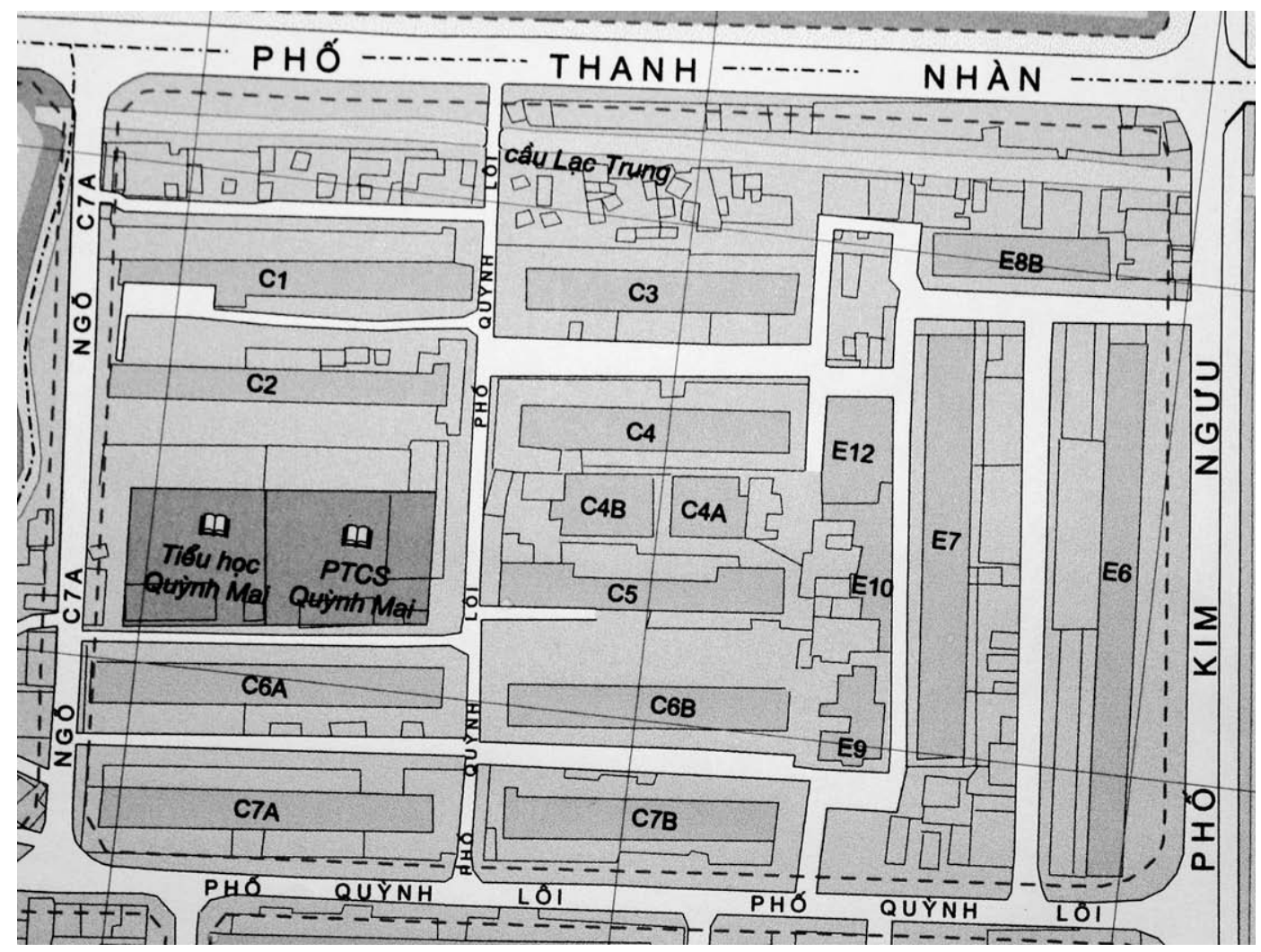

Fig. 2. Plan of part of Quynh Mai showing layout of original blocks and extensions.

homes into public spaces thus the streets have become 'an extension of domestic space, an annexation of commercial space and a space for personal expression' (Drummond, 2000: 2389).

The new market economy is providing some people with a chance for a better income and thus improved housing. Within Quynh Mai, extensions of apartments into public space for income-generating activities and for increased living space are widespread (Fig. 3). One such apartment is owned by Hung who works for a Japanese Vietnamese joint-venture company operating in the construction sector. He lives in Quynh Mai in a third floor apartment with his wife, daughter and younger brother. He inherited the apartment from his father who had been allocated it by his workplace. Hung bought the apartment during privatisation and subsequently built a large extension of $18 \mathrm{~m}^{2}$ which doubled the size of the apartment resulting in there being a bedroom, a modern kitchen and toilet (Fig. 4). The extension was possible because he managed to team up with other residents occupying flats in the same position from the ground floor to the fourth floor and a whole structure annexed to the original building was built. The original apartment is now used as a living room and to receive guests. The furnishing is much better than in the majority of apartments in Quynh Mai and the living room has a modern sofa set, display cabinet with a television set, a bookshelf and a stereo.

In the new economy, residents have more opportunities to earn a living because they can use their apartments, partially or wholly, for income-generating activities. This applies especially, though not exclusively, to those located on the ground floor. Prior to Doi Moi, these kinds of activities were often not allowed, though sometimes they were tolerated by the local authorities. At present, in the spirit of privatisation, control has been loosened and private construction is taking up much of the public space around the residential blocks. The most common and simple business for ground floor residents is the keeping of motorbikes and running of tea or small grocery shops in the front of the apartments. The largest private business encountered in an apartment in Quynh Mai was one where bike locks are being produced. Money earned from the business has enabled the owner to extend and improve the apartment. The original apartment, which was half an apartment $\left(10.5 \mathrm{~m}^{2}\right)$, belongs to an elderly woman, Mrs. Thuy, who still lives there. She was allocated the small apartment as she had lost her husband in the war and was alone with her son. As the apartment was on the ground floor she was subsequently able to enlarge it by extending into the surrounding public space gradually becoming $60 \mathrm{~m}^{2}$ in size. In 2001, when privatisation was implemented, Mrs. Thuy bought the apartment from the city and two years later her son bought the apartment directly above on the first floor. Internal stairs were added linking the two apartments and the inside has been modernised to such an extent that it no longer resembles a Quynh Mai apartment. The apartment now has a living room, four bedrooms, kitchen, bathroom and several rooms for the workshop. The household consists of five members as the son has married and has two teenage children. He and his wife now manage the lock making business which has been running for 20 years. The business has flourished in recent years and now takes up much of the ground floor of the house where seven employees work in dingy, deafening conditions.

The Vietnamese government is actively encouraging people to establish their own businesses, the rationale being that by becoming rich individually, people can contribute to the welfare of the nation (Turner and Nguyen, 2005). Another way of generating income from the home, which is common in many low-income housing areas, is renting out part of the home. Despite the small living areas, some households in Quynh Mai rent out rooms, especially those who have been able to extend their apartment. This was the case for an elderly couple who are retired workers from the textile factory. They have a ground floor apartment where they 


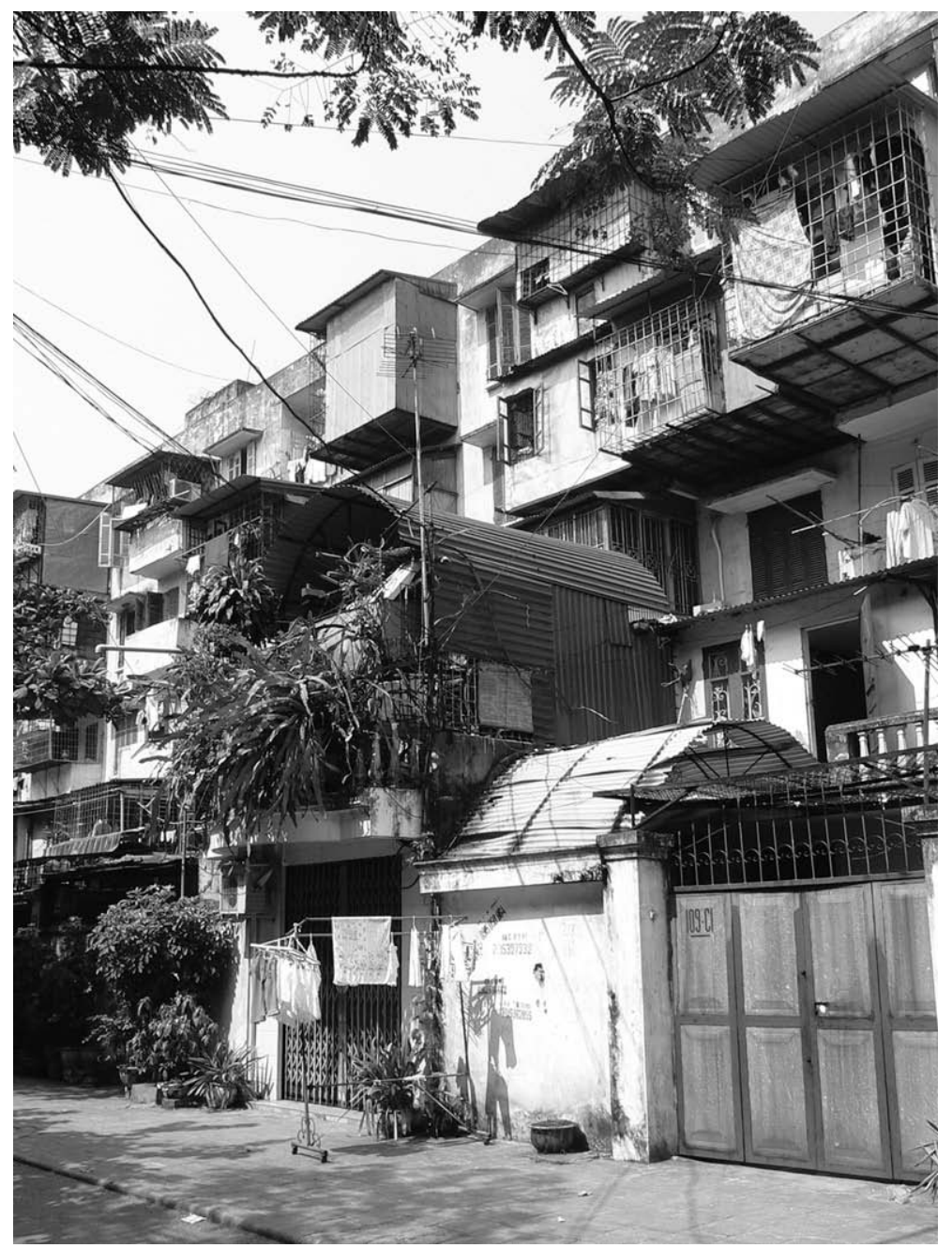

Fig. 3. Apartment block in Quynh Mai with numerous extensions.

raised their two children who are now in their 20s. As is the tradition in Vietnam, the daughter moved to live with her husband on marrying but the son has remained living with his parents. There are three rooms in the apartment. The original apartment now forms the middle room and is the elderly couple's bedroom. In front of this, an extension of $13 \mathrm{~m}^{2}$ has been built which is used as the kitchen/living room and is where the son sleeps. A larger extension of $21 \mathrm{~m}^{2}$ was built later at the back. This room was initially rented out and the rent was an important source of income for the family. However, when the son married he moved into the room with his wife and one year old son. In order to compensate for the lost income from renting, the front room was converted into a space for storing motorbikes and the fees charged provide an important alternative source of income to renting.

Far from everyone, however, is benefiting from the new economy. Especially low-skilled workers often have to work extremely long hours for low pay. For many of those working in the rapidly expanding informal sector, incomes are low and erratic. Consequently, many households do not have the resources to improve their often overcrowded and poorly maintained housing. Households headed by single women, and those with many dependants, especially face difficulties. This was the case for a household consisting of a widow in her 50s and her son in his 20s who live in half an apartment of $12 \mathrm{~m}^{2}$. Retired from her work at a pharmacy with a pension that is not enough to provide for herself and her son, Mrs. Chi works at home as a childminder. Unusually the apartment has been divided lengthwise and is extremely narrow (Fig. 5). The front part is used as a kitchen with a counter for cooking, a sink in one corner and a cupboard and refrigerator in the other. The rear part is used as a multi-functional space. At the back is Mrs. Chi's sleeping space which doubles as the space she uses as a childminder. Her son, who is studying, sleeps in the middle of the apartment. Mrs. Chi's main wish is to have her own toilet and bathroom but she does not have the resources to install them. She worries about the future as her son will soon finish his studies and is likely to marry but there is not enough space for him to live in the apartment with his family. Mrs. Chi pins her hopes on her son getting a good job, earning good money and finding them better housing elsewhere.

\section{New housing policy: supporting those favoured by the old system}

The withdrawal of the state from housing provision and management is an important component of the new housing policy. The existing state housing stock is being sold to sitting tenants and in order to accelerate the process, housing is being sold at highly subsidized prices. Since housing has long served as a form of remuneration, the government has granted a special reduction in house and land prices to reward loyal civil servants who have long service and those who made major contributions in the wars. At times, discounts have been so substantial that no money has ex- 


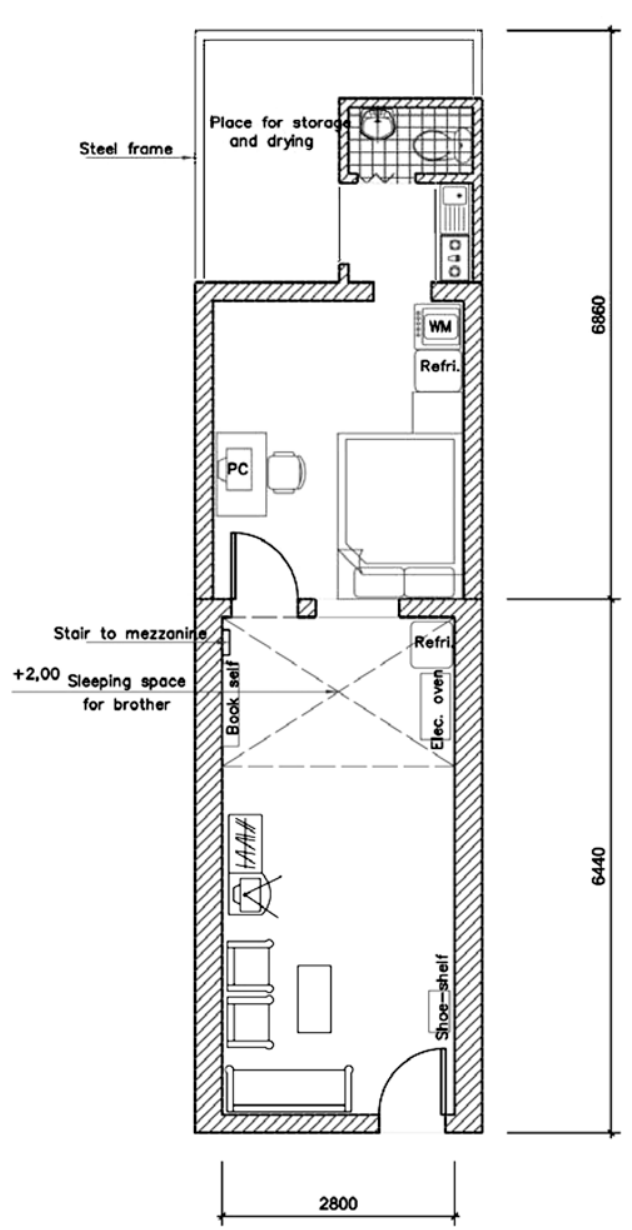

Fig. 4. Plan of Hung's apartment showing large extension.

changed hands. Some of the higher ranking officers have even been allocated two apartments enabling them to pursue a number of strategies: sell one apartment and use the money to upgrade the other, sell both and buy a new apartment in a modern housing area, or rent out one of the apartments generating a good income source. Privatization has thus provided certain people with a clear economic advantage.

The experiences of households living in Quynh Mai clearly demonstrate how the new housing policy, especially the privatization and sale policy, is continuing to support those who were well situated in the old system. As Quynh Mai originally belonged to a textile factory, it was a poorer housing area with fewer welloff residents compared with other housing areas which belonged to more powerful work places. There are few cases, therefore, of very big winners in Qunyh Mai, at least among the people who are still living there. Despite this, considerable differences can still be identified between the inhabitants. A senior governmental staff member, Mr. Tan, exemplifies someone who has benefited from privatisation. Mr. Tan and his elderly wife, both in their seventies, live in a second floor apartment of $28 \mathrm{~m}^{2}$. Both have retired from state employment; Mr. Tan was the vice-director of a hospital and had been allocated the apartment from his workplace. After privatisation he did not have to pay for the apartment since he had more than 30 years of employment and several medals from the war. The apartment consists of three rooms:

\footnotetext{
${ }^{3}$ Approximately 60 USD according to the exchange rate in 2005 (15,000 VND per USD dollar).
}

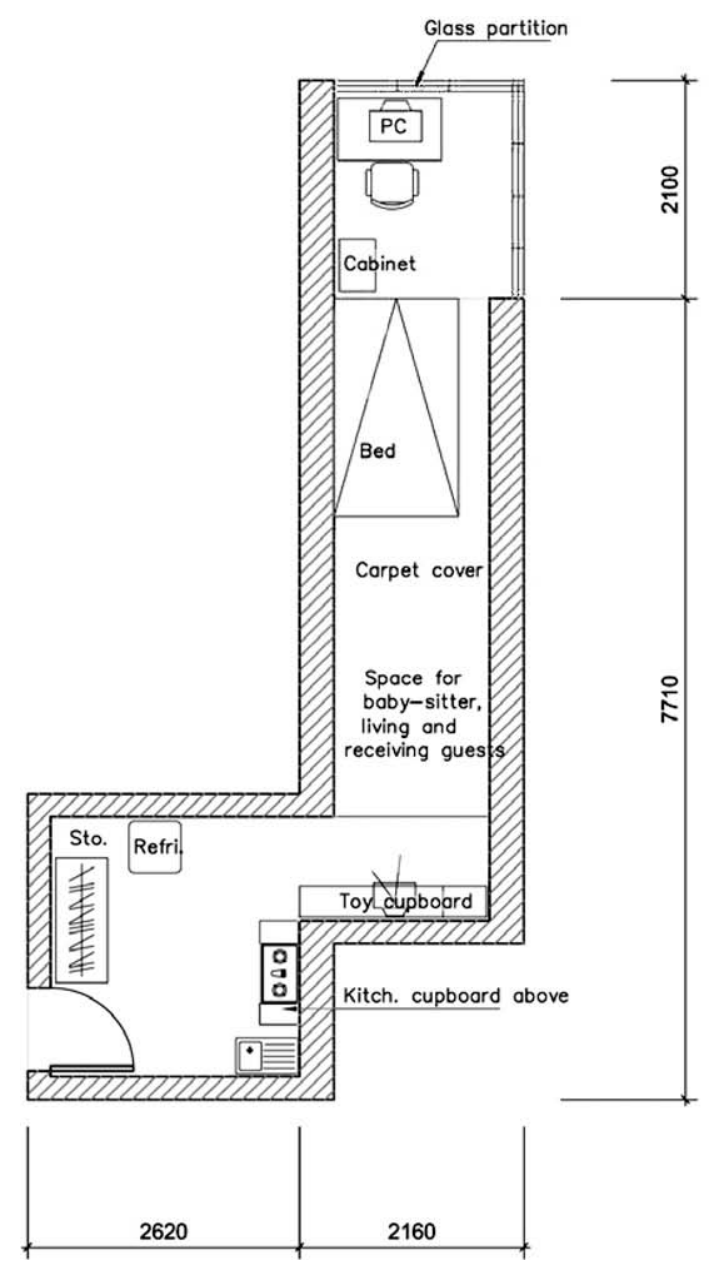

Fig. 5. Plan of Mrs. Chi's narrow apartment.

the front room has a sofa set and a small round table which serves as a dining area, the smaller room at the rear is used as a bedroom, and an extra room for guests has been made by extending the balcony. The apartment has been significantly upgraded and a toilet, wash basin, water heater and washing machine have been installed in the bathroom and the floor is newly tiled (Figs. 6 and 7).

While senior officers have received considerable state support, low ranked employees have not had the same help to improve their housing situation. This is the case for many of the retired or laid off workers from the textile factory who make up the majority of the population in Quynh Mai. Furthermore, many Quynh Mai residents have not benefited from privatization because the sale of apartments was stopped one year after its commencement as the buildings were considered to be in too poor a condition and needed to be upgraded before selling. Those who could not get their papers in order in time were deprived of the chance to buy. These were often the retired or laidoff workers, low rank employees and people with few connections and contacts, in effect often the poorest. One example is an elderly couple who are retired workers from the textile factory. They live in half an apartment, $11 \mathrm{~m}^{2}$, at the end of a corridor on the fourth floor of one of the oldest buildings in Quynh Mai. The front part of their apartment is used both as a living room and a kitchen (Fig. 8). One side is used for receiving guests, with a simple wooden table, and the other side is the cooking area. The bed occupies the rear part. The couple's only income 

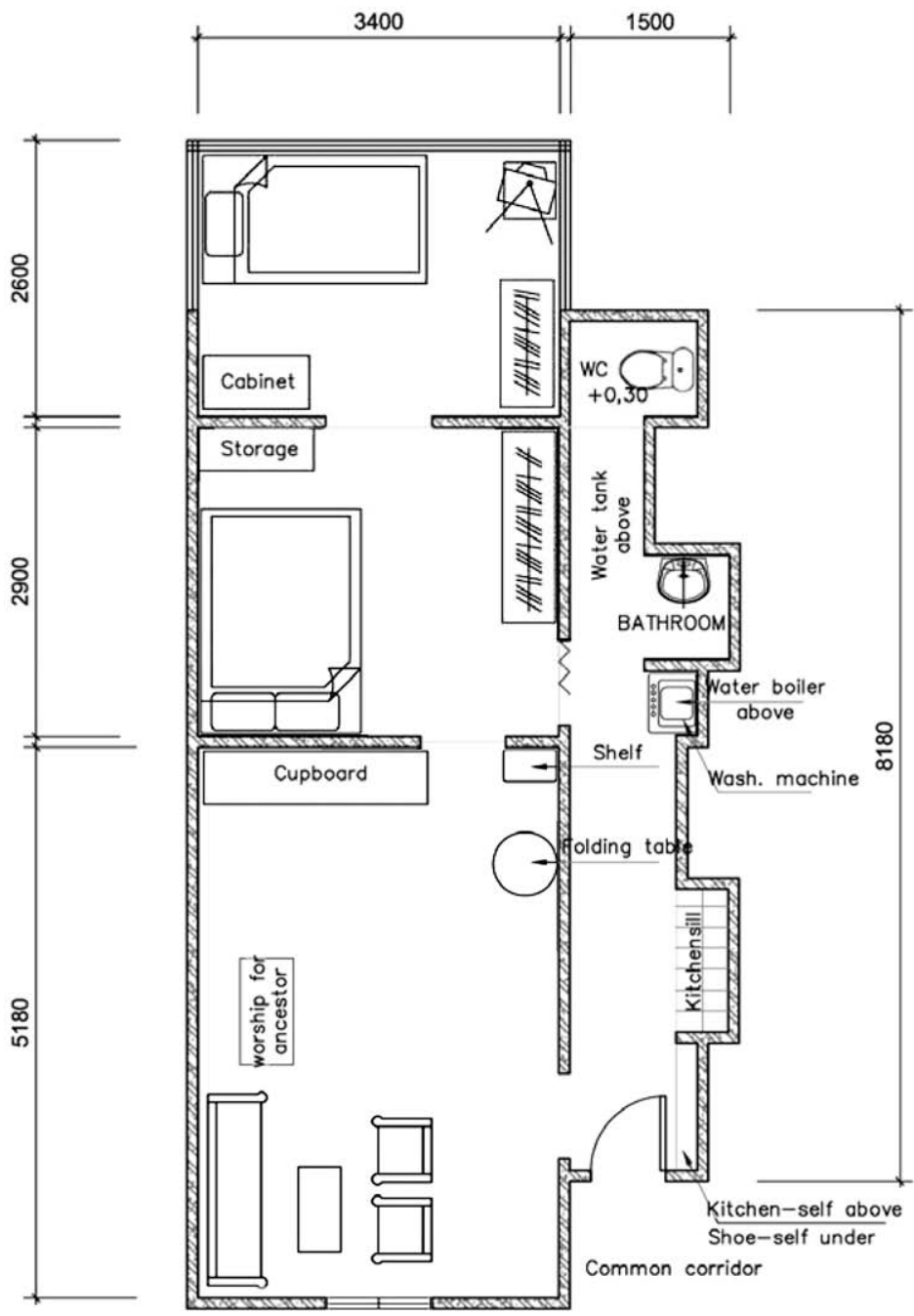

Fig. 6. Plan of Mr. Tan's substantially extended apartment

is their pensions of 900,000 VND per month, ${ }^{3}$ and they can hardly make ends meet. They were disappointed not to manage to buy their apartment before the sales stopped, as with their long history of employment and the low price of the flat they had hoped to become owners without making any payment. They are concerned that the redevelopment will result in much larger apartments which they will be unable to afford. As they maintained, 'We don't need many square meters. It would be good enough with $15 \mathrm{~m}^{2}$ and our own utility.'

By continuing to support some people within the state system, the new housing policy disadvantages low-income people who work in the private sector and were not qualified for state housing allocation in the first place. Those with a higher income or good business in the private sector often manage to procure housing and improve their living standards with their own capital. The subsidized sale price actually benefits those who have a reasonable income as they can buy into these housing areas. For low-income and poor households in the private sector, even the subsidised prices are well beyond their means. The situation is especially difficult for low-income households with one income earner and numerous dependants, many of which are female-headed households. One such case is Mrs. Nhu, a laid-off factory worker who is a widow liv-

\footnotetext{
${ }^{3}$ Approximately 60 USD according to the exchange rate in 2005 (15,000 VND per USD dollar).
}

ing with her three grown-up children in an $18 \mathrm{~m}^{2}$ apartment. Her income as a childminder (400,000-500,000 VND per month) is the only household income as none of her children are earning regularly; her eldest son is a drug addict, her youngest son is a casual

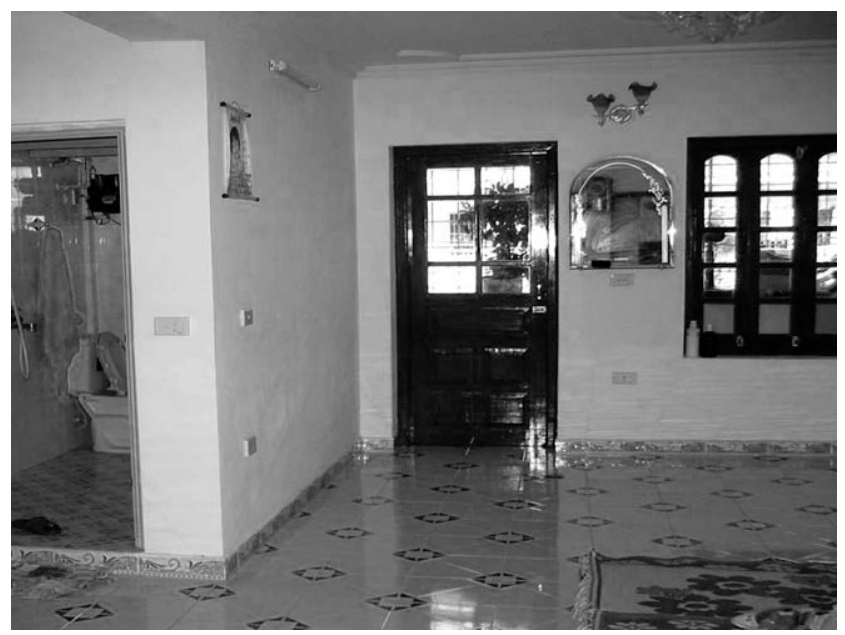

Fig. 7. Interior of an apartment which has been modernised. 


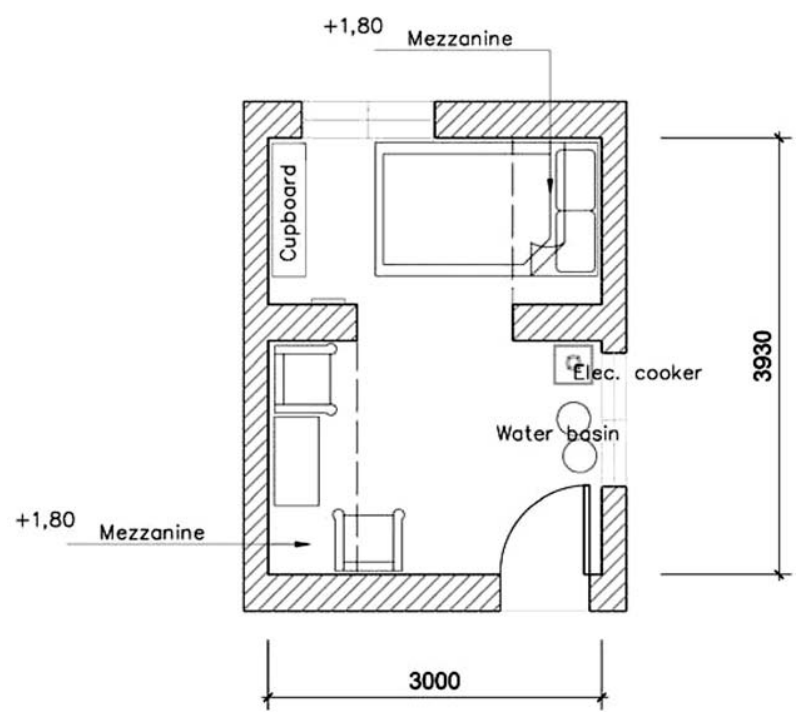

Fig. 8. Plan of a half apartment lived in by an elderly couple.

worker in the building trade but was out of work, and her daughter studies at college. Mrs. Nhu did not manage to get the owner's certificate before the sale stopped. She would like to become an owner as it would save her from paying the rent which would make her feel more secure. She was very disappointed that the sales had stopped and feels that the authorities have been unfair to her. Mrs. Nhu sees no possibility of improving her housing condition. Her greatest wish is to have her own toilet and bath facilities. Like others, she worries about redevelopment fearing that she will not be able to pay and so will not be allowed to stay in Quynh Mai. She and her family hardly have enough to survive on as it is now. As she said: 'We don't need a bigger apartment. We just want the government to give us our own utilities'.

\section{New housing market: unequal opportunities for youth}

The withdrawal of the state monopoly in housing, privatisation, as well as the participation of other actors in the housing sector, have created a new housing market in Hanoi. In this new system all households have to procure their own housing and state employees can no longer expect to have housing provided by the state. People who have capital, or have a good income, have a wider choice and more possibilities to find housing or improve their housing situation. However, those without capital, or on low-incomes, have great difficulties in finding adequate housing. One group that is particularly affected is young people who are trying to establish their own households. Youth aged 14-25 are currently the largest demographic segment constituting a quarter of the total population of Vietnam (Ministry of Health, 2005) and of these, nearly one in four live in urban areas (Dang et al., 2005). Young people in Hanoi consider early to mid twenties to be the ideal age for marriage but are concerned about how to financially support and house a family (Gough, 2008; Valentin, 2008). As Dang (2007) has indicated, the shift towards a market economy places new constraints on young people who are caught between old and new social norms and values.

Some young people are fortunate that their parents are able to purchase housing for them. Among those moving into Quynh Mai are students from other provinces who have come to study in Hanoi. Previously, these students had to live in rental accommodation but since privatisation some parents have bought apartments for them to live in. In Quynh Mai, a top floor apartment was being lived in by two brothers in their early 20s. The apartment had been bought by their parents for them to live in while they study in Hanoi. The young men use the front room of the two-roomed apartment as their living area and study which is furnished with two desks with chairs, a computer, and a large dresser. They share a large bed in the back room. The brothers only use the apartment to sleep and study in, spending the rest of their time at the university or in the centre of Hanoi, hence do not feel that they belong in Quynh Mai. The moving of new people into Quynh Mai is increasing the heterogeneity of the area and resulting in reduced social interaction between neighbours in many blocks.

For many young people, however, the new housing market puts them in a very difficult position. Those who work in the public sector are no longer allocated housing, and the commercial housing available in the market is too expensive for most young people. Affordable rental housing is difficult to find and many young people have to settle for long-term living in the parental home (Gough, 2008). Households with several young people who have formed their own families often have to subdivide their living spaces in order to accommodate them and have to accept overcrowding. In one

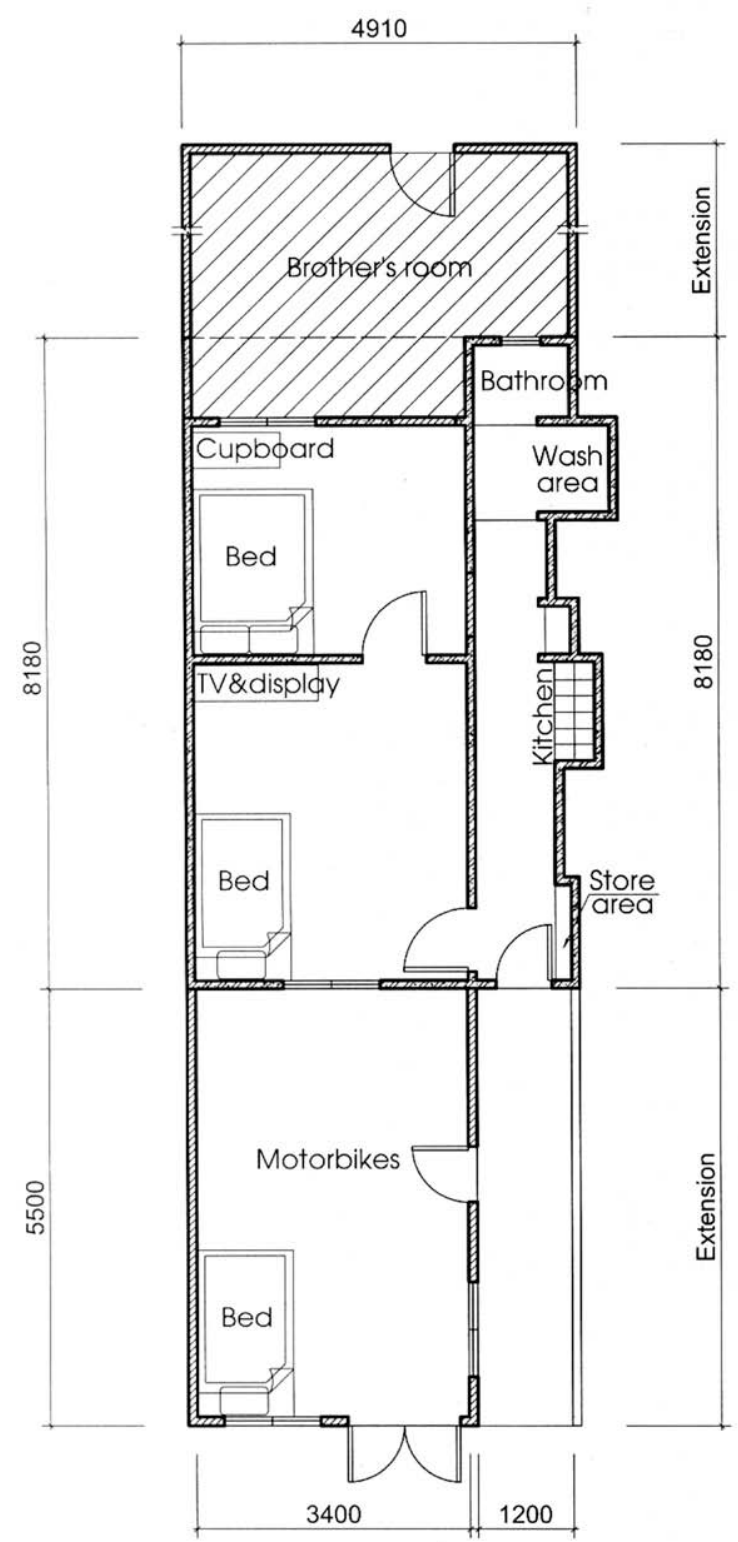

Fig. 9. Plan of ground floor apartment showing extensions at front and back used as living space and for generating income. 
(a)

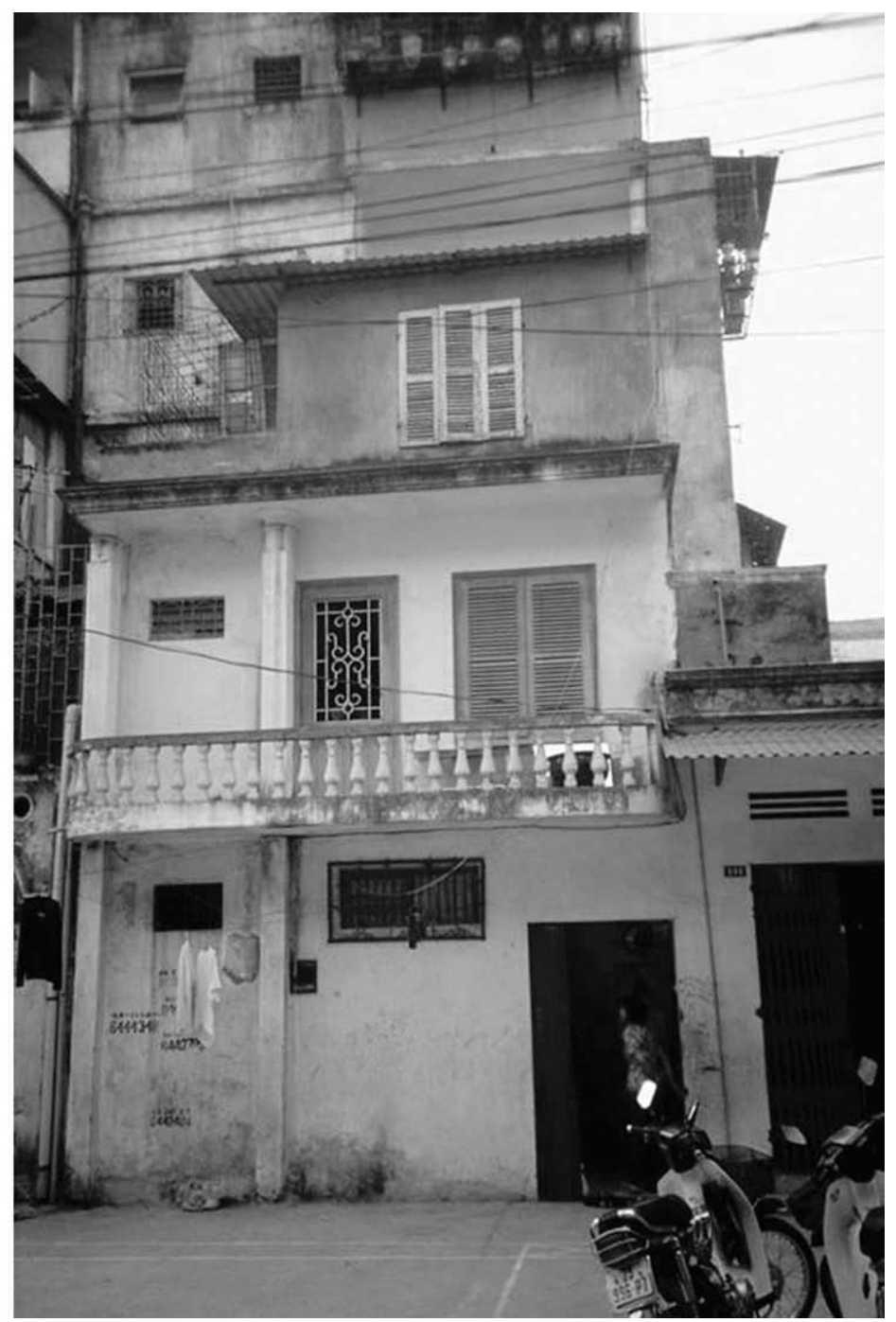

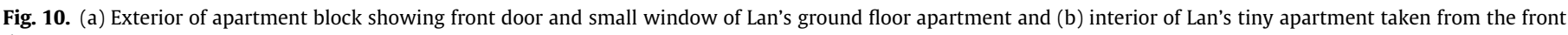
door.

such case in Quynh Mai, an apartment is occupied by an elderly couple with three sons, all in their 20s. After the eldest son married, the apartment was subdivided so that he could live with his wife and child in a room at the back of the apartment (Fig. 9). As the apartment is located on the ground floor, and had been extended both at the front and the back, it was possible to block off the connecting door to the rest of the apartment and build a new entrance at the back. There are three more rooms in the apartment. The youngest son sleeps in the room at the front which is filled with motorbikes stored for others at night. The next room is occupied by the other son, and the parents sleep in the living room. There is a long narrow kitchen with some space used for storage and a smart looking bathroom at the end. The family plan is to stop storing motorbikes so that the front room can be lived in and the apartment can be divided between the two younger sons when they form their own independent households. As one of the sons, who was working as an assistant in a workshop that makes industrial steel frames, said: 'Because my salary is low, with this current salary, it would take me 20 years more before I can buy a house. Therefore I will live here when I get married'.

When young people have to share overcrowded living space with their family it is common that young men are prioritised. Households are usually organised patrilineally, in terms of males being heads of households (Rydstrøm and Drummond, 2004), hence a woman is expected to leave the home on marriage to live with her husband and his parents. Married women who stay in the parental home are only considered to be living there temporarily and have to manage in whatever space is made available to them and their family. This was the case where a married woman Lan and her family were living in a subdivided apartment that had belonged to her parents. Lan's mother was no longer alive and her father had returned to his home village. The two elder brothers had subdivided the main apartment between themselves. When the living arrangements in her husband's parental home did not work out, Lan's brothers allowed her to move into the space that had been the entrance to the original apartment. Consequently, Lan was living with her husband and two daughters in a room of just $6 \mathrm{~m}^{2}$. The tiny room is very neat and tidy, consisting of a living area with a wall dividing it from a toilet and kitchen, with a sleeping area built halfway across the room at head height (Fig. 10a and b). At night not only does the small space of the living area become the sleeping area for the parents, it is also where the family's bicycle and motorbike are stored. As the door is metal, and there is only one very small window high up, their home becomes very hot in summer. However, despite the cramped living conditions, she preferred it to living with her in-laws as it was her space. 


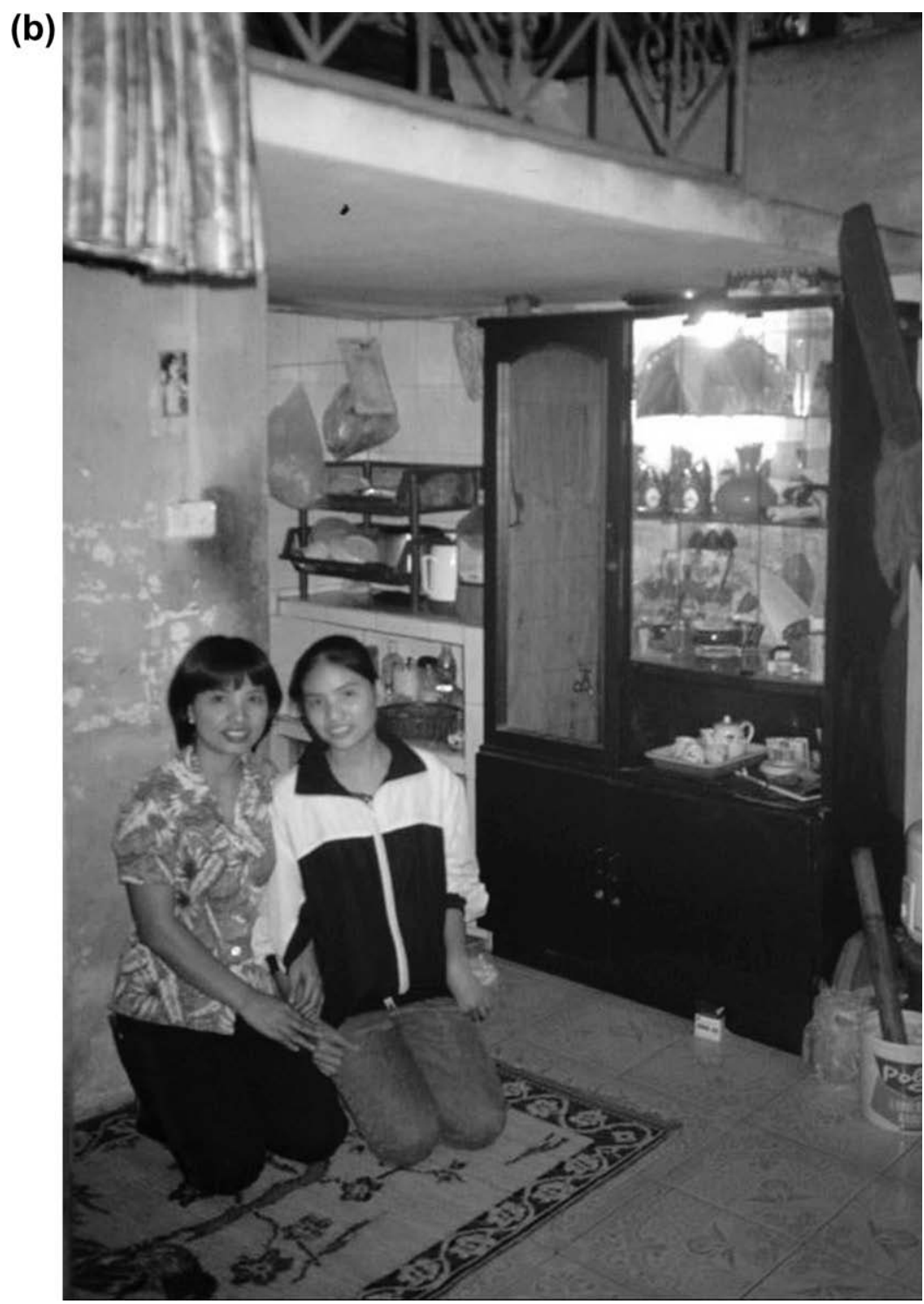

Fig. 10 (continued)

\section{Conclusions: unequal opportunities in Quynh Mai}

The shift to a market-oriented economy has brought about many changes in the Vietnamese economy and society. There has been consistently fast growth of national income, per capita GDP has quadrupled, and there has been rapid reduction in poverty (Beresford, 2008). The unevenness of these improvements, however, has been widely reported (Dixon, 2003; Beresford and McFarlane, 1995; Beresford, 2003; Vietnam Development Report 2004, 2003). As well as regional inequalities emerging, social inequality, in particular the widening gap between the rich and the poor, is rising. As King et al. (2008) have highlighted, 'winners' and 'losers' have been created and social class divisions have widened. This is resulting in an increasingly complex and diverse social order emerging in Vietnam caught in the contradictions between a state ideology which still espouses a socialist ideology based on notions of equality, and government policies which are directed to integrate Vietnam into a global market-based economy and encourage social mobility and the accumulation of wealth.

In the field of housing, privatisation and the termination of state monopoly in housing production and provision have significantly changed the housing situation of many residents. Who are the winners and the losers in this new housing market? This paper has addressed this question through focusing on the residential area of Quynh Mai with its Soviet-style apartment blocks. A range of households have been shown to be able to improve their housing situation. These include those for whom the transition to a market economy has brought about new ways to make a living which in turn has enabled them to invest in improving their homes. Another group which has benefited are former senior officials, often now retired, who were well situated in the old hierarchy. They continue to be favoured in the new housing policy and can thus improve their housing situation. Furthermore, some young people, in particular those whose parents can afford to buy housing for them, have also benefited.

Despite a substantial group of residents having been able to improve their housing situation since transition, many households face an uncertain housing future. Low-income households, whose members are often self-employed working in the low-pay service sector, have little or no possibility of improving their housing situation. Although some can afford to make modest changes to their homes, most have found themselves stuck in a run-down housing 
area that requires more substantial changes than they can afford. People working in the private sector, who were excluded in the old housing system, are now further neglected in the new policy. Even lower level government employees, who do not have the benefits of higher level employees, are facing economic difficulties and are receiving little or no support in the new policy. Young people are particularly disadvantaged; few of those who are employed by the state can expect state housing provision, and with little hope of establishing their own dwelling many have to settle for long-term living with their parents. Cramped living conditions and subdivision of living spaces to accommodate multiple nuclear households living under one roof has become common. Young women tend to be particularly disadvantaged as parents make housing plans for their sons rather than their daughters who are expected to leave the parental home on marrying; those who remain at home after marriage are considered to have less right to live there. As Turner and Nguyen (2005, p. 1706) found, young people in Vietnam are facing new challenges 'as they come to terms with operating within an increasingly market-based economy, instead of gaining a position in the socialist state sector through powerful patron-client connections as was the case for their parents'. This is as true for the housing sector as it is for the economy and is not exclusive to youth in Vietnam. As Jeffrey and McDowell (2004, p. 132) have argued, young people in many parts of the world 'are trapped between declining state support and increasing familial and personal ambitions'.

Unequal housing opportunities are not only found between different social groups but also have a spatial dimension. The possibilities of extending apartments are unevenly distributed according to their spatial location. Ground floor residents have immediate access to public land in front of and behind their apartments on which they can build large extensions. Apartments at the end of blocks on the ground floor can also extend sideways. Although those located higher up can make smaller extensions which hang in mid-air, or larger ones that build on top of existing extensions lower down, their possibilities are more limited. Additionally, in the new market-oriented economy, a ground floor location increases the opportunities of using extra space for income-generating activities, such as a tea or grocery shop, or for services such as the parking of motorbikes or a barber shop. Waibel (2004) identified similar trends in the Ancient Quarter of Hanoi where the conversion of street fronts into retail space by tube house residents has intensified the polarisation of income structures. Another consequence of these extensions is the transgression of the distinction between public and private space which, whilst not a new process, has been accentuated in the new economy. As Drummond (2000, p. 2378) has argued, 'families and individuals make use of so-called public space for private activities to an extent and in ways that render public space notionally private'.

The findings of this paper add to claims that social inequalities are increasing in Vietnam. These inequalities are found not only between differing residential areas but also within them. Although on the surface the opportunities of the residents of Soviet-style apartment blocks appear to be similar, in practice they differ considerably. While the move to a market economy has generated inequality through differentiated income-generating opportunities, the unequal housing options in Quynh Mai are also the result of the new housing policy. This policy provides commercial housing for the better off and prioritises a chosen group of state employees who gain both from the discount policies of housing privatisation and as the main beneficiaries of recent housing directives, most explicitly expressed in the directive on social housing (Tran and Yip, 2008). Thus, the new housing system generates a new inequality at the same time as it strengthens an old one. As such it still neglects substantial groups, especially those who are involved in informal economic activities. Consequently, 'The trend towards increased inequality requires a deep reconsideration of public expenditure and public investment programs' (Vietnam Development Report 2004, 2003, p. xiv).

Housing reforms in other transitional societies have also been shown to result in increased social and residential inequalities. This has been the case in several transitional societies in Eastern Europe (see Vesselinov, 2004; Mandic, 2001; Sykora, 1999) and in China (Logan et al., 1999; Zhang, 1999; Wang and Murie, 2000; $\mathrm{Wu}, 2002$; $\mathrm{Li}$ and $\mathrm{Wu}, 2006$ ) where state power and the old hierarchy persist. At the level of the individual, political capital also continues to provide benefits for those who possess it (Bian and Logan, 1996). Similarly, despite moving towards a market economy, the new housing system in transitional Vietnam is still built on old ideologies and supports the old hierarchy. However, unlike in other transitional countries, Vietnam does have social ambitions to address the housing situation of socially disadvantaged groups (Tran and Yip, 2008). These attempts will not succeed though until the old value system, which provides preferential treatment to state workers, is changed. In order to achieve a more equitable housing system, Vietnam needs to formulate housing policies that are based on the demand and address the housing needs of all citizens. These policies need to be coupled with more equitable allocation mechanisms to ensure that housing in Vietnam reaches the target groups.

\section{Acknowledgements}

Katherine Gough would like to thank Dang Nguyen Anh and Karen Valentin and for their logistical assistance in setting up the fieldwork in Quynh Mai, which was funded by the Council for Development Research of the Danish International Development Agency (DANIDA). Nghiem Thi Thuy assisted in arranging the interviews and Nguyen Chung Thuy was a very competent interpreter. Hoai Anh Tran would like to thank Nguyen Thuy Dung for assistance in the interviews and for the drawings of the apartments which Lars Landin kindly edited. Her field study was carried out within the framework of a research project funded by the Swedish Agency for Research Cooperation (SAREC) of the Swedish International Development Authority (SIDA). Kent Pørksen assisted with the maps.

\section{References}

Beresford, M (2003) Economic transition, uneven development and the impact of reform on regional inequality. In Post War Vietnam: Dynamics of a Transforming Society, H V Luong (ed.), pp. 55-80. Rowman and Littlefield, Lanham.

Beresford, M (2008) Doi Moi in review: the challenges of building market socialism in Vietnam. Journal of Contemporary Asia 38(2), 221-243.

Beresford, M and McFarlane, B (1995) Regional inequality and regionalism in Vietnam and China. Journal of Contemporary Asia 25(1), 50-72.

Bian, Y and Logan, J R (1996) Market transition and the persistence of power: the changing stratification system in urban China. American Sociological Review 61(5), 739-758.

Dang, N A (2007) Youth work and employment in Vietnam. In Social issues under economic transformation and integration in Vietnam, Giang Than Long and Duong Ki Hong (eds.). Vietnam Development Forum.

Dang, N A, Duong, Le Bach, D and Nguyen, H V (2005). Youth employment in Viet Nam: characteristics, determinants and policy responses. Employment Strategy Papers, International Labour Organisation.

Dixon, C (2003) Developmental lessons of the Vietnamese transitional economy. Progress in Development Studies 3(4), 287-306.

Drakakis-Smith, D and Dixon, C (1997) Sustainable urbanization in Vietnam. Geoforum 28(1), 21-38.

Drummond, L B W (2000) Street scenes: practices of public and private space in urban Vietnam. Urban Studies 37(12), 2377-2391.

Gough, K V (2008) Youth and the home. In Youth and the City in the Global South: Urban Lives in Brazil, Vietnam and Zambia, K T H Hansen, A L Dalgaard, K V Gough, U A Madsen, K Valentin and N Wildermuth (eds.). Indiana University Press, Bloomington.

Hansen, K T H, Dalgaard, A L, Gough, K V, Madsen, U A, Valentin, K and Wildermuth, (2008) Youth and the City in the Global South: Urban Lives in Brazil, Vietnam and Zambia. Indiana University Press, Bloomington.

IICA (Japan International Cooperation Agency) and Hanoi People's Committee (2007). The Comprehensive Urban Development Programme in Hanoi Capital 
City of the Socialist Republic of Vietnam (HAIDEP), Final Report, Living Condition Sub-sector, March 2007.

Jeffrey, C and McDowell, L (2004) Youth in a comparative perspective: global change, local lives. Youth and Society 36(2), 131-142.

Kim, A M (2007) North versus South: the impact of social norms in the market pricing of private property rights in Vietnam. World Development 35(12), 20792095.

King, K T, Nguyen, P A and Minh, N H (2008) Professional middle class youth in postreform Vietnam: identity, continuity and change. Modern Asian Studies 42(4), 783-813.

Leaf, M (1999) Vietnam's urban edge. Third World Planning Review 21(3), 297-315.

$\mathrm{Li}, \mathrm{Z}$ and $\mathrm{Wu}, \mathrm{F}(2006)$ Socio-spatial differentiation and residential inequalities in Shanghai: a case study of three neighbourhoods. Housing Studies 21(5), 695-717.

Logan, W S (2000) Hanoi: Biography of a City. University of Washington Press, Seattle.

Logan, J R, Bian, Y and Bian, F (1999) Housing inequality in urban China in the 1990s. International Journal of Urban and Regional Research 23(1), 7-25.

Luan, T D (2000) Hanoi: some changes in the contemporary urban life and appearance. In Shelter and Living in Hanoi, T D Luan and H Schenk (eds.). Cultural Publishing House, Hanoi.

Luan, T D and Vinh, N Q (2001) Socio-Economic Impacts of 'Doi Moi' on Urban Housing in Vietnam. Social Sciences Publishing House, Hanoi.

Ministry of Health (2005). Survey Assessment on Vietnamese Youth. Ministry of Health, General Statistics Office, Hanoi.

Phe, $\mathrm{H} \mathrm{H}$ (2002) Investment in residential property: taxonomy of home improvers in Central Hanoi. Habitat International 26, 471-486.

Quang, N and Kammeier, H D (2002) Changes in the political economy of Vietnam and their impacts on the built environment of Hanoi. Cities 19(6), 373-388.

Rydstrøm, H and Drummond, L (2004) Gender Practices in Contemporary Vietnam. NIAS Press.

Smith, D W and Scarpaci, J L (2000) Urbanization in transitional societies: an overview of Vietnam and Hanoi. Urban Geography 21(8), 745-757.

Surborg, B (2006) Advanced services, the new economy and the built environment in Hanoi. Cities 23(4), 239-249.

Sykora, L (1999) Processes of socio-spatial differentiation in post-communist Prague. Housing Studies 14(5), 679-701.
ThanhnienOnline 19/11/2007 (2007). Hanoi: Nhung kien nghi moi ve ban nha 61 (Hanoi: new proposals on the sale of state owned housing according to Decree 61), November 19, 2007, available at <http://www1.thanhnien.com.vn/Nhadat/ 2007/11/20/216539.tno> (accessed June 2008).

Thomas, M (2002) Out of control: emergent cultural landscapes and political change in urban Vietnam. Urban Studies 39(9), 1611-1624.

Tran, H A and Dalholm, E (2005) Favoured owners, neglected tenants: privatisation of state owned housing in Hanoi. Housing Studies 20(6), 897-929.

Tran, H A and Yip, N M (2008) Caught between plan and market: Vietnam's housing reform in the transition to a market economy. Urban Policy and Research 26(3), 309-323.

Trinh, P V and Parenteau, R (1992) Housing and urban development policies in Vietnam. Habitat International 15(4), 153-169.

Turner, S and Nguyen, P A (2005) Young entrepreneurs, social capital and Doi Moi in Hanoi, Vietnam. Urban Studies 42(10), 1693-1710.

Valentin, K (2008) Politicized leisure in the wake of Doi Moi: a study of youth in Hanoi. In Youth and the City in the Global South: Urban Lives in Brazil, Vietnam and Zambia, K T H Hansen, A L Dalgaard, K V Gough, U A Madsen, K Valentin and N Wildermuth (eds.). Indiana University Press, Bloomington.

van Horen, B (2005) City profile: Hanoi. Cities 22(2), 161-173.

Vesselinov, E (2004) The continuing 'Wind of Change' in the Balkans: sources of housing inequality in Bulgaria. Urban Studies 41(13), 2601-2619.

Vietnam Development Report 2004 (2003) Poverty. Joint Donor Report to the Vietnam Consultative Group Meeting Hanoi, December 2-3, 2003.

Waibel, M (2004) The Ancient Quarter of Hanoi - a reflection of urban transition processes. ASIEN 92, 30-48.

Wang, Y P and Murie, A (2000) Social and spatial implication of housing reform in China. International Journal of Urban and Regional Research 24, 397-417.

$\mathrm{Wu}, \mathrm{F}$ (2002) Social spatial differentiation in urban China: evidence form Shanghai's real estate market. Environment and Planning A 34, 1591-1615.

Yeung, Y (2007) Vietnam: two decades of urban development. Eurasian Geography and Economics 48(3), 269-288.

Yip, N M and Tran, H A (2008) Urban housing reform and state capacity in Vietnam. The Pacific Review 21(2), 189-210.

Zhang, X Q (1999) The impact of housing privatisation in China. Environment and Planning B 26, 593-604. 